\title{
MIKS KÕNELEB LAOKOON KIRJASÕNAS JA EI KÕNELE MARMORIS?
}

See, kes esimesena pü̈̈dis maalikunsti ja poeesiat omavahel võrrelda, oli erksa tundevõimega inimene, kes märkas, et mõlemad kunstiliigid tema peale ühesugust mõju avaldavad. Ta leidis, et mõlemad kujutavad kaugeid, olnud asju kui vahetuid, näilikkust tegelikkusena, mõlemad petavad, ja mõlema pete pakub meile naudingut. ${ }^{1}$

Gotthold Ephraim Lessing, 1766

Miks siis kõneleb Laokoon luulekeeles ja ei kõnele marmoris? Miks erutab juba toona ligemale paari aastatuhande vanune kuju ikka veel kunstist kirjutajate meeli? Mis on üldse kunst? Kas pettus, mis võib pakkuda naudingut, nagu väidab Gotthold Ephraim Lessing oma 1766. aastal Laokooni grupile pühendatud essee algusosas. Või on kunstis varjul sügavamad allikad, mis aitavad meil mõista inimest, mis haaravad täielikult meie kujutlusvõimet ning milles kunstnikud ei suuda olla

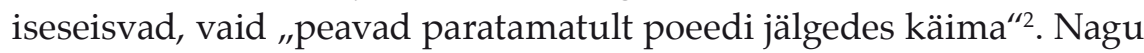
paljud enne teda (ja ka pärast), annab Lessing eelistuse sõnale, mis võrreldes kujutava kunstiga ei ole mitte üksnes kergemini mõistetav ja täpsem, vaid võimaldab ka asjadest ja nende põhjustest kõneleda selgemalt ning tõepärasemalt. Pildi ja sõna vastastikuses suhtes on sõnal tõe kuulutajana roll. Ja ometi võib ka sõna petta.

Nii nagu kujutav kunst, jääb ka luule kinni omaenese poolt loodud kujundite ja metafooride võrku, väljendades seda, mida maailma kohta

DOI: http://dx.doi.org/10.12697/BJAH.2016.11.02

1 Gotthold Ephraim Lessing, „Laokoon ehk maalikunsti ja poeesia piiridest“, Valitud teosed (Tallinn: Eesti Raamat, 1965), 327.

2 Ibidem, 356. 
arvame mitte otse, vaid kaudselt, kasutades sõnu nagu ehituskive oma sümboolse templi püstitamiseks. Sarnaselt pildiga, on sõna mõistusele lõpuni kättesaamatu, tema juured peituvad meie mütoloogilises alateadvuses, kust seda on üritatud kinni püüda ja ära seletada. Juba Johann Gottfried von Herder teadis, et sõna ürgne loomus jääb inimesele igavesti saladuseks. 20. sajandil välja kujunenud lingvistiline filosoofia on koguni loobunud otsimast paralleele sõna ja tegelikkuse vahel, leppides teadmisega, et erinevad keeled võivad nii oma semantika kui grammatikaga väljendada maailma erinevalt, pakkudes võimaluse verbaalseid sõnumeid küll uurida ja teaduslikult kirjeldada, aga mitte kunagi otsustada, milline siis ikkagi on maailm, milles toimime.

Lessingi keelemeisterlik essee haarab ühel igivanal probleemil taas korra sarvist. Tema kirjatöös kõnelevad kaasa nii mineviku tarkus kui tormi ja tungi ajastu poeedi mässumeel, mis sunnib kahtlema autoriteetides. Alustades Johann Joachim Winckelmanni kritiseerimisega ja loetledes oma suure eelkäija möödalaskmisi antiigi tundmises, pühendus autor oma teksti järgmistes osades kahele peamisele teemale. Neist esimene võtab üles juba renessansiajal paragone nime all puhkenud diskussiooni maalikunsti eelistest skulptuuri ees ja nende mõlema suhtest poeesiaga, teine keskendub kunsti gnoseoloogilisele küljele, milles autori sõnade taga võime leida descartes'liku skepsise mitte iialgi pidada tõeliseks seda, mida me ei ole võimelised tunnetama kui loodust: „Need, kel on kõige võimsam arusaamine ja kes tungivad kõige paremini oma mõtetesse, et neid teha selgeks ja arusaadavaks, võivad alati kõige paremini veenda, kuigi nad räägiksid ainult alambretooni keeles ega tunneks üldse retoorikat; ja need, kes evivad kõige meeldivamaid väljamõeldisi ning kes oskavad neid avaldada suurima ilu ja armsusega, on siiski parimad poeedid, olgugi et poeetiline kunst on neile tundmata..”3

On vähe tõenäoline, et tänast lugejat võiksid huvitada Lessingi arvamused, mis puudutavad kreeka kirjanduse ajalugu ja veel vähemgi siis Winckelmanni suuremaid või väiksemaid faktilisi möödalaskmisi. Osaliselt on need tingitud klassikalise arheoloogia toonasest seisust, osalt kindlasti ka Winckelmanni loomusest, mis empiirilisele analüüsile eelistas nii mõnelgi puhul spontaanset ja hingestatud sõna. Vastupidi Winckelmannile ei tunne ega mäleta me Lessingit kunstiajaloolasena. Ka ei määra kunstiajalugu oma konventsionaalsete meetoditega kuigivõrd

3 René Descartes, Arutlus meetodist (Tallinn: Olion, 1995), 130. käesoleva essee sisu. Pigem on tähelepanu orbiidis kaks valgustusajastul kristalliseerunud erinevat suhtumist kunstiajaloo kirjutisse, selle ideedesse ja eesmärkidesse, millest üks juhib meid kunstiajaloo kui antikvaarse suunaga akadeemilise teaduse ja laiemalt empiirilise teadmise juurde ning teine esteetika kui Alexander Gottlieb Baumgarteni poolt mõisteliselt formuleeritud lähenemise poole. ${ }^{4}$ Neil mõlemal on nähtavasti omad plussid ja miinused. Tavapärane on kõneleda Winckelmannist kui kunstiajaloolasest ja vähem kui filosoofist ja poeedist, lastes end seeläbi eksitada diskursuslikult välistavatest meetoditest ja jättes seejuures puudutamata tema rolli kuulutaja ning omamoodi prohvetina, kellele subjektiivne kunstikogemus ja selle väljendamine luulelises keeles seostus ajastule omase vaimse kliima ja retoorilise paatosega. Oleme Winckelmanni enamasti lugenud ühekülgselt, pööranud tähelepanu tema intellektuaalsele poolele, jättes kõrvale talle samapalju omase hingelise ja romantilise külje, ilma milleta ei ole Winckelmanni ja enamasti ka kunstiteost võimalik mõista ega ka kirjeldada.

Kõige laiemas mõttes on igasugune vahetegemine ratio ja tunnete vahel kunstlik. Nagu William Guild Howard juba sada aastat tagasi kirjutas, on Winckelmanni „Antiikkunsti ajalugu“ samahästi nii süstemaatiline ülevaade kunsti perioodidest kui näide metafüüsilise ajaloo tunnetuse kokkupuutest kreeka vaimse kultuuriga. ${ }^{5}$ Apollonliku alge kõrval elab tema kirjutistes dionysoslik lähenemine, mille sõnum on pigem joobumuslik ja afektiivne ning tugineb meelte poolt mõistusele vahendatud ettekujutustele. Mida valgustusajastu kunstiajalugu, niipalju kui see oli omaette distsipliinina olemas, teadis ja ka rõhutas. „Kunsti abil me mitte ei mõtle, vaid loome kujundeid“, väidab Immanuel Kant. ${ }^{6}$ Kunst avab värava väga isiklikule ja unenäo sarnasele reaalsusele, kus teos on haaranud oma aine välispidisest, peegeldab seejuures aga veelgi enam

4 Esteetika algne tähendus seostub mimeesisliku protsessiga, milles välisilma objektid loovad meelte vahendusel teadvuses vaimseid kujundeid. Göran Sörborn, The Classical Concept of Mimesis. A Companion to Art Theory, ed. by Paul Smith, Carolyn Wilde (Oxford: Blackwell Publishing, 2002), 20 Keskajal tegid skolastikud vahet aisthēta ja noèta vahel, millest esimene seostub sellega, mida vahendavad meile meeled, teine sellega, mida annab meile teada intellekt. Ikoonimaalis väljendub esteetika teose joone, värvi ja kompositsiooni põhimõtetes. Esteetika mõiste kaasaegse tähenduse võlgneme Alexander Gottlieb Baumgartenile, kes oma 1735. aastal publitseeritud doktoritöös andis sellele tunne-
tusteoreetilised raamid. Vt Alexander Gottlieb Baumgarten, Meditationes Philosophicae de Nonnullis tusteoreetilised raamid. Vt Alexander Gottlieb Baumgarten, Meditat
ad Poema Pertinentibus (Halle: Joannis Henrici Grunerti, 1735). 5 Laokoon. Lessing, Herder, Goethe. Selections, ed. by William Guild Howard (New York: Henry Holt Company, 1910), $162 \mathrm{jj}$.

(Cambridge, Massachusetts, London: Harvard University Press, 2015), 5. 
sisemist reaalsust, mille algallikad on meile silmaga nähtamatud ja elavad salapärasena geeniuse võimes avada inspiratsiooni abil teine ja veelgi olulisem reaalsus.

Mainitu ei ole öeldud selleks, et tõsta päevakorrale üht järjekordset intriigi. Juba mõnda aega otsib kunstiajalugu endale humanitaarias aset leidnud pöördeliste muutuste taustal uusi perspektiive. Keskendumise asemel ajaloolisele narratiivile on tõusnud taas korra arutluse keskpunkti kunsti kokkupuude filosoofilise mõtisklusega, milles visuaalne kujund kui primaarne ja sõltumatu kontseptsioon ( $\mathrm{kr}$ noēsis) äratab verbaalselt väljendatavaid ideid maailma kohta, kandes endas ühelt poolt varakristliku Jumala meenutust ja teiselt poolt renessansiajastu ruumi ja perspektiivi õpetuse pitserit. ${ }^{7}$ Kunsti ambitsiooniks on tegeleda kõige olulisemaga, kõneleda substantiivsetest väärtustest, olla ühtaegu nii usutunnistus kui pakkuda võimalusi maailmavaateliste ja eetiliste tõdede väljendamiseks. Sündmusi illustreeriva ja deskriptiivse kunsti asemel kõneleme kunstist, mis iseseisva kunstilise reaalsusena pakub välja tervikpildi ja süsteemi, kui mitte kogu kõiksuse (kr apeiros), siis vähemalt selle füüsilise osa ( $\mathrm{kr}$ apeiros physis) mõistmiseks.

Sarnaselt keelefilosoofiale ja sellele iseloomulikule keelelisele pöördele, on viusaalkultuuris leidmas aset (seda küll teatava ajalise nihkega) pildiline pööre, mille alguse juures võime olla tunnistajaks, kuid mille lõpp on sama palju ebaselge ja hämar kui kuuvalgus valgustusajastu kunstnike müstilistel öömaastikel. Kunsti nähtava osa, mida on võimeline väljendama visuaalne grammatika, kõrval kuulub oluline roll ka nähtamatule, kõigele sellele, mis asub pildi sees, kohal või taga ning mis teeb kunstist kunsti ja mis tänu sellesse kätketud metafüüsilisele sõnumile intrigeerib otsima kunstiteoste kirjeldamisel üha uusi väljendusviise ja vahendeid. Laias laastus sarnaneb olukord pildi mõistmisel ja ära seletamisel situatsiooniga, mida tõdeme verbaalsete tekstide puhul. Vanad meetodid ei toimi, uusi aga veel ei ole, mis nii kunstist kui kirjandusest kirjutajates sünnitab ebakindlust ja ehk ka hirmu eksida. „Ebastabiilsus, mis korduvalt häirib struktuurilist pilti, tekib vahetult selle põhialuslikust kohustusest. /---/ See kohustumine nõuab, et tavaline lingvistiline kasutus oleks kirjeldatav kui reeglite ehk korrapärasuste kogu /---/, see lootus mängib jätkuvalt määravat rolli analüütilises traditsioonis, kuigi

William John Thomas Mitchell, „The Pictorial Turn“, Picture Theory: Essays on Verbal and Visual Representation (Chicago, London: University of Chicago Press, 1994), 23. nende spetsiifiliste filosoofide empiirilised ja positivistlikud kohustumised on juba ulatuslikult ümber lükatud.“8

Kuna prognoosida tulevikku on keerulisem kui pöörata pilk tagasi minevikku, soovitan oma alljärgnevas essees pöörata tähelepanu ühele kultuuride ajaloos filosoofilisemale ajastule - valgustusajastule, mis mõõdetava kõrval tõstis esile mõõdetamatu ${ }^{9}$ ja välise vormi kõrval sisemise tule. Klassitsismiajastu kunsti tähendused ei peitu mitte niivõrd jäljendamise ja kaanoni vallas, vaid avavad end sügavama tõena, mille lugemiseks vajame kahekordseid prille, leidmaks tekstis taaskord üles selle algideed, muutes visuaalse sõnumi filosoofiaks ja luuleks. Mis toob valgustusajastul domineerinud klassika retseptsiooni varjust välja selle tähendusliku poole, jagades selle mitte üksnes stiiliajaloolisteks perioodideks (vara-, kõrg- ja hilisklassitsism), vaid seostada need vaimuloomingu mõttelise poolega, nagu Winckelmanni utoopiaihalus, Kanti üleva mõiste või siis Hegeli pürgimus absoluudi poole. ${ }^{10}$

Mida ootame tänaselt kunstilt (nii nagu ka enamiku teiste perioodide kunstilt) on tahe otsida ja leida vastus eksistentsi olulisematele küsimustele, mille kaudu oleme valmis mõistma mitte üksikut igas tema eripärasuses, vaid tervikut kui universaalset ideed. See hõlmab nii intellekti pürgimusi tõe järele kui tundeelamusi, mille kaudu mõistame maailma mitte paljude erinevate artefaktide summana, vaid summana, mis ühe ja sellesama hingetõmbega on võimeline pakkuma meile ainulaadse tõehetke, mis oma joonte, värvide ja kompostisooni kooskõlas äratab vaimu ja lahvatab valgussähvatusena Giorgione maalil „Il Tramonto“. Aristotelesliku püha empiirika asemel, mis valitses 19 sajandi kunstiteadust ja mis tekstile eelistas konteksti, kõike seda, mis oli toimunud kunsti ümber - olgu selle näiteks toodud biograafiline meetod või kunstisotsioloogia -, otsime kunsti puhul taas seda toitvat ideed; st vastust 20. sajandil ja Wittgensteini poolt peaaegu keelu alla pandud küsimustele: mis on kunst, milleks kunsti vajame ning millised on piirid kunsti ja näiteks teaduse või tehnika vahel.

Enam kui varem huvitab meid kunsti puhul selle loomise algpõhjused, seal hulgas inimvaimu toitev fantaasia, mis toob alateadvuse introvertselt suletud tagatubadest esile olulise, muutes hämarad ettekujutused kirkaks

8 Paul M. Livingston, Philosophy and the Vision of Language. Routledge Studies in Twentieth-Century Philosophy (New York, London: Routledge, 2008), 13.

guin Books, 1968), 54

10 Juhan Maiste, Klassitsism ja tõde“, Kunstiteaduslikke uurimusi, 17 (1-2) (2008), 11. 
ja kindlustades ideele vormi. ${ }^{11}$ Taas korra julgeme kõneleda üksikisiku geeniusest ja talle ainuomasest inspiratsioonist, mida Platon kirjeldas "püha andena“ ja mis nagu „magnetiline kivi liigutab raudrõngaid“. ${ }^{12}$ Vabanenuna konventsionaalsetest tõekspidamistest, on kunstnik vaba väljendama oma isiklikke tundeid, arvamusi, läbielamusi. Sama kehtib ka vaataja suhtes, kellele on antud võimalus ja õigus väljendada oma arvamusi lühidalt ja konkreetselt: „meeldib“ või „ei meeldi.“ Ilma, et ta seejuures peaks tundma muret oma otsustuste tagajärgede pärast. Vähemalt on sellisel arvamusel siinkirjutaja.

Kunstiteadusele tähendab see täiesti uut olukorda. Pilt või siis ruumiline kujund, milledele valgustusajastul kujunes välja eriline lähenemine - kunstiajalugu seadis eesmärgiks sõnaliselt lahti harutada ja ära seletada, otsides seeläbi sidet teaduse objektiivsete meetoditega -, kaugeneb Winckelmanniga seostatavast kunstiajaloo käsitlusest ja sellele omastest objektiivsetest meetoditest. Ja küsib endale kohta mitte ainuüksi analüütilise, vaid üha enam fenomenoloogilise lähenemise vallas. Kõneledes kunstiajaloo surmast, nagu sellest viimasel ajal on kirjutatud ${ }^{13}$, mõtleme tegelikult kunstiajaloo ühe suuna ja meetodi ammendumisele, mis lausa iseenesest seab meid küsimuse ette, kas peavoolu kõrval eksisteerib ka veel mõni teine lähenemine, mis esialgu niriseva ojaveena uuristab kaljut, millel seisab akadeemiline teadus. Kuidas ja kas üldse peaksime kunstist kirjutama? Või siis peaksime komponeerima kunstiteosest lähtuva muusikateose, mis oma helide kõla ja rütmiga vastab kunstniku poolt loodud maalikunsti ideele? Kas selleks, et kirjutada ajalugu peab olema Herodotose vaimus ajaloolane või siis hoopis poeet, kes küsimuse kõrval, mis siis tegelikult juhtus, on vaba vastama ka küsimusele, mis oleks võinud juhtuda? ${ }^{14}$ Kas Laokoon kunstiteosena on võimeline

11 Pean siin silmas Platoni poolt kirjeldatud mälu seletust, milles fantaasiale (phantasma) on reserveeritud koht jäljendava kujundi loomise näol, muutes sarnasuse uueks nähtavaks ikooniks (eikōn). V Paul Ricoeur, Memory, History, Forgetting (Chicago, London: The University of Chicago Press, 2006), 11. 2 Plato, „Ion“, Aesthetics. A Comprehebsive Anthology, ed. by Steven M. Cahn, Aaron Meski Oxford: Blackwell Publishing, 2008), 18.

13 Whitney Davis, „Winckelmann Divided: Mourning the Death of Art Histroy“, The Art of Art History: A Critical Anthology, ed. by Donald Preziosi (Oxford, New York: Oxford University Press 1998), $40 \mathrm{jj}$. Alex Potts, Flesh and the Ideal. Winckelmann and the Origins of Art History (New Haven London: Yale University Press, 2000), 40 jj.

14 „Sest ajaloolane ja luuletaja ei erine mitte selle poolest, kas nad kõnelevad värssides või värssideta (võimalik oleks ju ka Herodotose teos värssidesse ümber panna ja ikkagi oleks see ajalugu, värsimõõdu niisamuti kui ilma värsimõõduta), vaid selle poolest, et üks kõneleb toimunust, teine aga sellest, mis ajalugu aga üksikust." Vt Aristoteles, Luulekunstist, tlk Jaan Unt (Tallinn: Keel ja Kirjandus, 2003), 9. väljendama niisama sügavaid tundeid nagu hädakarjed Loakooni kui kirjandusliku kuju huulilt?

Võrreldes keelefilosoofiaga on kunstiteadusel üks märkimisväärne erinevus. Ajal, mil 20. sajandil formuleerus pööre humanitaarias, ei produtseerinud kunstiteadus samasuguseid kriitilisi tekste, vaid jätkas Erwin Panofsky ja Ernst Gombrichi poolt etteantud radadel, valides oma meetoditeks ikonoloogia ja seda toetava antikvarismi, mis lõid sideme kunstisotsioloogia ja kunstiinstitutsioonidega, nagu mõnikord öeldud, „nurrus salongide ja muuseumide seinte vahel.“15 Neokantiaanlik asetumine, mis iseloomustab tänast mõttelugu, ei ole senini leidnud kunstiajaloo metoodikates oma kohta ja praktilist kasutamist. Lõhe filosoofia ja kunstiajaloo vahel on sama suur kui erinevus pildi ja sõna vahel, mis on seadnud barjääri küsimaks kõige olulisemaid küsimusi kuidas võiksime kunstist rääkida? Kas siis tunderõhkude ja pausidega, nagu arvas luule puhul Lessing, või siis mõistuspäraselt ja põhjendatult, mis vastaks akadeemilisele teaduskirjutise normidele?

Andes aukoha sõnale, oleme kunstist kõnelemisele andnud tõlketeksti tähenduse, mis toob meieni teadmise vitede vaimus kunstnike elulugudest, poliitilistest oludest, kunsti sotsiaalsest determineeritusest, teose psühholoogilisest mõjust meie meeleorganitele, värvidest, toonidest ja pooltoonidest. Kogu kunsti äärmuseni subjektiivsest loomusest hoolimata, otsime sellele objektiivsest alust, mis lubaks kunsti painutada teleoloogilise ajalookäsitluse raamidesse, mis sarnaselt teadusega käsitleb kunsti muutuva ja madalamalt kõrgematele arenevate vormide reana. Üliõpilastelt olen sageli kuulnud väidet, et 20. sajandi kunst on juba oma eeldustelt midagi hoopiski paremat ja kõrgemat kui kogu eelnevate sajandite poolt loodu. Minu poolt esitatud küsimusele, miks küll siis, on vastuseks imestunud kulmude kergitamine, kuidas küll võib õppejõud esitada sedavõrd naiivseid küsimusi. Hegellik absoluutse vaimu ihalus joonistab kunstiajaloo ette esteetilise täiustumise tee, mida jätkavad nii lääne kultuuriajaloo kesksed universaalse kunstiajaloo käsitlused kui sellest inspireeritud rahvuslikud kunstiajalood.

Ja seda ajal, mil hermeneutiline ajalookäsitlus on igasuguse ühesuunalise progressi mõiste jätnud kas täiesti kõrvale või kasutab seda üksnes lisaargumendina teatavate kunstiilmingute seletamisel. Mis kunsti-

15 Mark A. Cheetham, Kant, Art, and Art History. Moments of Discipline (Cambridge: Cambridge University Press, 2001), 21. 
ajalool oma võitluses sageli ühekülgselt mõistetud stiili- ja vormiajaloo vastu märkamata on jäänud, on põhimõtteline muutus, mille vahetuks tunnistajaks oleme olnud ja mis ühel või teisel moel toovad meid tagasi valgustusajastul formuleeritud määratlemata ja ebaselgete mõistete juurde, nagu enesereflektsioon, autoanalüüs ja elamuslik kunstikäsitlus. Seisame sealsamas, kust kunagi algasime ja mis on inspireerinud Hans-Georg Gadameri kirjutama: „Vastused, mida uusaja kolme sajandi vältel on leitud, kõlavad küll erinevalt, kuid nad on vastused samale küsimusele, ja hilisemad vastused pole varasemateta võimalikud ja peavad nende ees vastu pidama. ${ }^{16}$

Taas seisame ühe tee alguses, mille puhul meenub üks Herderi poolt kunagi kord ümber jutustatud Aisopose mõistulugu rumalast hundist ja targast rebasest, kes õppis ära inimeste keele ja sai inimese sõbraks. ${ }^{17}$ Hunt, kes keelt ära ei õppinud, jäigi aga rumalaks. Olles teadlik endale seatud ülesande keerukusest, ei loobu ma ometi otsimast vastust küsimusele, mis on kunst ja millised on võimalused sellest aru saada või koguni mõne teise meedia vahendusel lahti mõtestada ja ära seletada? Kuidas võrrelda maalikunsti skulptuuriga ja neid mõlemaid luulega? Kas siin tegemist teineteist toetava või siis vastupidi kahe erineva fenomeniga, millest üks juhatab meid kunsti mõistmise ajaloolise ja teine filosoofilise lähenemise poole? Kuidas tõlkida ühte kujundikeelt teise? Kuidas anda ühele ettekujutusele ja märksüsteemile koht teises? Kuidas ühendada kaks inimvaimu poolust - pilt ja sõna - ühtsesse tervikusse, kus neil mõlemal on koht inimvaimu lakkamatus pürgimuses tõe üha täpsema tunnetuse ja selle intellektuaalse määratlemise poole.

Olen arvamusel, et asjadest, millest mõnikord arvatakse, et ei peaks kõnelema, on siiski parem rääkida. Rääkimise ja selleks kasutatava sõna kaudu mõistame iseennast. Rääkimine võimaldab meil avaldada omaenese arvamust ja leida kontakt teiste arvamustega. Kunstiajaloo ülesandeks on muuta kunsti salapärane ja peidetud sisu mõistetavaks, seletada lahti tunne, mida kutsub esile maal, skulptuur või pargimaastik, mille sõnalise ekvivalendina sobivad nii proosatekst kui luule, ja mis mõlemad alates Winckelmanni aegadest elavad teineteise kõrval. Kunsti ja luule koha üle

16 Hans-Georg Gadamer, Hermeneutika universaalsus. Valik esseid ja intervjuusid (Tartu: Ilmamaa, 2002), 29,59

17 Johann Gottfried Herder, Abhandlung über den Ursprung der Sprache: Welche den von der Königl. Akademie der Wissenscahaften für das Jahr 1770 gesezten Preis erhalten hat (Berlin: Christia Friedrich Voß, 1772), 71, 99-100. meie maailmapildi osa ja seletajana võib küll diskuteerida, vaevalt küll võiksime seejuures nõustuda Lessingi arvamusega, mis Euroopa ühe tuntuma kunstiikooni Laokooni puhul ahvatles teada küsima: kuivõrd on valge ja siledaks poleeritud marmorpind võimeline kõnelema inimesele omastest kõige sügavamatest tunnetest, nagu hirmust, õudusest ja piinast? Kas õudus saab hääle Trooja preestri karjeks avatud marmorsuul?

Winckelmannile ja Lessingile järgnesid Herder ja Goethe, kes kirjutades Laokoonist, andsid sellele filosoofilise metafoori tähenduse, mille kaudu sisemine avab end välimises ja kujule omane vorm ning stiil leiavad endale koha nii minevikus kui hetkes, mil silmitseme kuju uuesti. Uus on äraunustatud vana, Laokoonist kirjutades mõjuvad 18. sajandi suurmeeste teosed kaasaegsema ja meile olulisemana kui seda oleme ehk söandanud endale tunnistada. ${ }^{18}$

\section{LAOKOON JA ANTIKVAARNE TRADITSIOON}

Läbi aegade on Laokooni imetletud ja temast ka kirjutatud. Esimese kirjelduse Laokoonist pakub välja Plinius Vanem, kes oma "Loodusloo“ (Naturalis historia) 36. raamatus peatub pronksist valmistatud grupil, pidades seda paremaks kui ükskõik millist teist maalikunsti või skulptuuriteost. Ühes Tituse villadest asunud Laokooni autoritena nimetab Plinius kolme Rhodose kunstnikku: Hagesandrost, Polydorost ja Athenedorost. ${ }^{19}$ Koos Rooma langusega vajus Laokoon unustusse ja leiti 1506. aastal Santa Maggiore katedraali lähistelt Esquiliniumilt. Kui isa parem käsi ja poegade mõlemad käed välja arvata, oli skulptuurigrupp säilinud terviklikult. Apollo Belvedere järel, mis oli leitud juba mõnikümmend aastat varem, oli tegemist kõige olulisema teosega, mida paavst Julius II käsul leidu üle vaatama saadetud skulptor Giuliano da Sangallo kirjeldas järgmiselt: „Paavst andis Giulianole käsu minna ja vaadata

18 Käesolevas artiklis on kasutatud 1910. aastal ilmunud Lessingi, Herderi ja Goethe Laokooni teemalisi tekste: Laokoon. Lessing, Herder, Goethe. Selections, ed. by William Guild Howard (New York Henry Holt Company, 1910). Möödunud saja aasta jooksul on paljud Howardi vaated leidnud ümbe hindamist, kuid tänaseni on antud käsitlus ainuke, mis vaatleb probleemi terviklikuna, koondades ühiste kaante vahele ka kolm esteetika ajaloo tüviteksti: Gotthold Ephraim Lessing, Laokoon. Ode über die Grenzen der Malerei und Poesie. Mit beilüufigen Erläuterungen verschiedener Punkte der alten Kunstgeschichte (1766); Johann Gottfried Herder, Abhandlung über den Ursprung der Sprache: Welche den von der Königl. Akademie der Wissenscahaften für das Jahr 1770 gesezten Preis erhalten hat; Johan Wolfgang Goethe, Über Laokoon (Propyläen. Ersten Bandes Erstes Stück, 1798). 19 Sarah Blake McHam, Pliny and the Artistic Culture of the Italian Renaissance. The Legacy of the
Natural History (New Haven, London: Yale University Press, 2013), 54 . 
üle äsja ilmsiks tulnud kujud. Kohe asuti teele, kaasa tuli Michelangelo Buonarroti, keda võis päevast-päeva leida meie majas ja kelle minu isa oli nimetanud paavsti hauaskulptuuri valmistajaks. /---/ Mina ronisin alla kujude juurde ja minu isa lausus sel samal hetkel: See on Laokoon, mida mainib Plinius. Seejärel kaevati auk laiemaks nii, et Laokooni võis tõsta üles. Niipea kui kuju ilmus nähtavale, hakkasid kõik seda joonistama ja muistsetest asjadest kõnelema.“20

Laokooni leidja sai vaevatasuks 300 tukatit ja igavese rahuplatsi Santa Maria di Aracoeli kirikus Kapitooliumi mäel. Laokoon paigutati Julius II-le Bramante poolt ehitatud Cortile de del Belvedere paviljoni, kus see Apollo Belvedere, Heraklese torso jt antiikkunsti meistriteoste kõrval asub tänaseni. Peaaegu hetkega oli Laokoon võitnud kõige laiema tähelepanu. 1510. aastal ilmunud nn Albertini giidiraamatus kirjeldatakse Laokooni kui kõigi aegade parimat meistriteost. Bramante algatas võistluse ainulaadse kunstišedöövri restaureerimiseks. Kujust valmistat vahakoopia. Laokoonile lisati puuduv käsivars. Veneetsia antikvaari kardinal Domenico Grimani eestvõtmisel valati marmorkujust võetud jäljendus pronksi, mida François I ihaldas oma Fontainebleau kogudesse. Clemens VII käsul anti koopia siiski üle Medicist paavsti sünnilinnale Firenzele, kus see Uffizi galerii ühe kõige atraktiivsema eksponaadina köidab külastaja pilku tänaseni. 18. sajandil sai Laokoon tuntuks arvukate muuseumide, aadlipaleede ja mõne aja möödudes ka ülikoolide interjööre ehtivate marmorist, pronksist ja kipsist valmistatud koopiate näol. ${ }^{21}$

Laokooni on restaureeritud üha uuesti ja uuesti, liidetud ja siis taas eemaldatud jäsemeid vastavalt sellele, mida on ette kirjutanud kunstimaitse ja muinsuskaitse filosoofia. Michelangelo arvates olevat figuurigrupi sünnitanud „püha anne“. Millele vaatamata soovitas ta Fra Angelo Montorsolil modelleerida Trooja preestri kaduma läinud käsivars, kasutades selleks terrakota laadsest savisegu. Nii oli võimalik eristada originaal koopiast, esialgne fantaasiapilt Laokoonist restauraatori ettekujutusest, pannes sellisena aluse kaasaegsele muinsusfilosoofiale, mille eesmärgiks on rõhutada nii kunstiobjekti dokumentaalseid kui ka esteetilist tervikut rõhutavaid väärtusi. Täna on 16. sajandil lisatud jäse kuulutatud omaette kunsti-

20 Francesco da Sangallo mälestused, mis on esmakordselt trükitud: Carlo Fea, Miscellanea filologica critica e antiquaria (Rooma: Pagliarini, 1790), 329. Tsiteeritud: Francis Haskell, Nicholas Penny, Taste and the Antique. The Lure of Classical Sculpture, 1500-1900 (New Haven, London: Yale University

21 Haskell, Penny, Taste and the Antique. The Lure of Classical Sculpture, 1500-1900, $243 \mathrm{jj}$. teoseks ja asetatud kuju kõrvale. Aastal 1905, kui Roomast leiti Trooja preestri oletatav käsivars, kinnitati see kuju külge oma arvatavale kohale. ${ }^{22}$ Tänaseks on kõik hilisemad lisandused eemaldatud.

Laokoon on lääne kultuuri üks kõige olulisemaid sümboleid, millest on ikka ja jälle kirjutatud. Kunstiajaloolasi on huvitanud, kas tegemist on Kreeka Pergamoni stiilis originaali või siis Rooma töökodades valmistatud koopiaga. On koguni avaldatud arvamust, et algselt koosnes skulptuurigrupp ainult isa ja ühe poja kujust. Arvamusi on teisigi. Iga ajastu näeb Laokooni ja selle kultuuriajaloolisi tähendusi omamoodi, tõstatades juba olemasolevate küsimuste kõrvale üha uusi, mis lõppkokkuvõttes ei välista aga kõige olulisemat küsimust - n-ö küsimuste küsimust: mis siis ikkagi on see erakordne, mis sunnib Laokooni kohta võtma sõna? Miks seisatume Laokooni ees? On selleks kunst või hoopiski ajalugu, mis kokku moodustavad nii Winckelmanni aegse kui tänase kunstiajaloo käsitluse meetodi ja telje nurgakivi.

\section{WINCKELMANN VERSUS WINCKELMANN}

Nii nagu kunstil ja sellest kirjutaval kunstiajalool, on ka selle aluse rajajal Winckelmannil kaks teineteise suhtes vastandlikku loomust, millest üks vastab välimisele ja teine sisemisele loomusele. Manerismiajastu disegno interno sünnib vaimse kujundina, võimaldades meil näitlikustada ja selgitada kõiki seda, mis võib olla ja tegutseda vastavuses meie poolt kavatsetavale (Frederico Zuccari). ${ }^{23}$ Winckelmanni eelkäija Giovanni Pietro Bellori järgi sünnib kunst loodust imiteerides, kuid on sellest ometigi suurem, väljendades tundeid, mis on omased üksnes kõrgemale teadvusele ning mis iga üksikfiguuri ja vormi veatuses ületab looduse. ${ }^{24}$ Vorm, mis on omane kogu nähtavale maailmale, peidab endas sellest sügavamat ideed, mis Winckelmanni poolt formuleeritud „rahuliku suursugususe ja õilsa lihtsuse" varjust toob esile pürgimuse vaimu kõige kõrgemate sfääride poole, pakkudes võimaluse valgustusaega käsitleda

22 Laokooni restaureerimise osas vaata lähemalt: Jukka Jokilehto, Arhitektuuri konserveerimise ajalugu (Tallinn: Eesti Kunstiakadeemia, 2010), 44.

23 Tsiteeritud: Mosche Barasch, Theories of Art. From Plato to Winckelmann (New York, London: Routledge, 1985), 300.

24 Giovanni Pietro Bellori, The Lives of the Modern Painters, Sculptors and Architects. A New Translation and Critical Edition, ed. by Alice Sedgwick Wohl, Hellmut Wohl, Tomaso Montanar (Cambridge, New York, Melbourne, Madrid, Cape Town, Singapore, São Paulo: Cambridge University
Press, 2005), 58 jj. 
nii klassikakaanoni raames kui romantilise ihalusena tõesema ja ilusama järele. „Nagu meri oma sügavuses jääb alati rahulikuks, kui palju ta ka ei tormitseks pinnal, niisamuti väljendavad Kreeka figuurid möllavate kirgede puhul suurt ning rahulikku hinge“, kirjutab Winckelmannile viidates Lessing. ${ }^{25}$ Johann Georg Hamanni järgi kuulub Winckelmanni kunstiajaloole koht poeesia ja kunstide vallas, neist seejuures karvavõrdki taganemata. ${ }^{26}$ Winckelmanni igatsedes, mõtleme nii tema intellektuaalsele pärandile kui tema iseloomu hämaramale poolele, mis elab kusagil tunnete sügavustes ja mida me lõpuni ei tunne..$^{27}$

Winckelmann jätkab kohast, mille olid kätte näidanud inglise sentimentalismi esindajad alates David Hume'ist. Meie teadmine maailma kohta põhineb meeltel. Aistingute kaudu mõistame ümbritsevat: loodust, ühiskonda, inimest. Tundefilosoofia määrab 18. sajandi saksa valgustusajastu esteetikat just samavõrra kui ratsionaalne teaduslik lähenemine. ${ }^{28}$ Meeleline kogemus on aluseks ettekujutustele, mis võimaldavad „looduse ülesseadmise (dispositio naturalis) saada kättesaadavaks meeltele (sensum) ja fantaasiale (phantasia), juhtides meid teravmeelse ande poolt lihvitud tunnetuse poole.“29 Winckelmanni suunajateks olid John Baillie ja Edmund Burke, kelle poolt esile toodud subliimsuse mõiste hõlmab meelte seisundite kõrval ka vaimseid seisundeid, mis avalduvad nii ilu kui hirmu- ja õudustunde näol. ${ }^{30}$

„Ükskõik siis, mis erutab valu ja hirmutundeid, ükskõik siis, mis tõstab esile hirmutundeid või vastab meis sündivale hirmutundele või hirmuäratavatele objektidele või siis mõjub meile sarnaselt hirmutundele, on subliimsuse jõud, see on kõigist emotsioonidest tugevaim, mida vaim on võimeline tundma. /---/ Ja kuna valu on tugevam kui naudingutunne, nii nagu surma idee ületab koguni valu, on surm kõigist emotsioonidest tugevaim. Kui hädaoht või valu on meile liiga ligidal, ei saa nad meile anda mingitki meeldivuse tunnet, nad on lihtsalt kohutavad, vaid tea-

25 Lessing, „Laokoon ehk maalikunsti ja poeesia piiridest“, 332.

26 Tsiteeritud: Udo Kultermann, Geschichte der Kunstgeschichte. Der Weg einer Wissenschaft (Wien, Düsselforf: Prestel, 1996), 56

27 Karl Morgenstern, Johann Winkelmann. Eine Rede. Über den Einfluss des Studiums der Griechischen und Römischen Classiker auf harmonische Bildung zum Menschen (Leipzig: G. J. Göschen, 1805), 5. 28 Ernst Cassirer, Schaftesbury und die Renaissance des Platonismus in England, Vorträge der Bibliothek Warburg, I (1930/31). Tsiteeritud: Kultermann, Geschichte der Kunstgeschichte. Der Weg einer Wissenschaft, 39 .

29 Alexander Gottlieb Baumgarten, Aesthetica (Halle: Johannis Christian Kleyb, 1750), 13.

30 Philipp Shaw, The Sublime. The New Critical Idiom (London, New York: Routledge. Taylor \& Francis Group, 2006), 48-49. taval kaugusel ja teatavate muudatustega, võivad valu ja hirm pakkuda rõõmu, nagu seda kogeme päevast-päeva. “31

Ilu äratundmiseks vajame nii allika-puhtaid silmi kui vaimset valmisolekut, millega kaasneb ülev tunne, mis „haarab vaatajat kõikvõimsa teisena, kui jumal siseneb ja võtab haldusesse vaataja ja sunnib tema suu vaikima /---/ tabades vaatajat nagu äikesetorm või välgunool.“32 Õilsa kontuuri kõrval on maalikunstis oluline ülev hing. ${ }^{33}$ Juba 1719 aastal tõstis maalikunstnik ja esseist Jonathan Richardson oma arutluste keskmesse Laokooni. ${ }^{34}$ Winckelmann üksnes jätkab traditsiooni. „See hing kujutab ennast kõige tugevamas kannatuses Laokooni näos, ja mitte ainult näos. See valu, mis ennast avaldab kõigis keha lihastes ja kõõlustes, ja mida arvatakse niisama, ilma et nägu ja teisi osasid vaadelda, peaaegu ise tunda valusalt sisse tõmmanud alakeha kannatusi See valu, ütlen ma, avaldub kõigest hoolimata ilma mingisuguse raevuta näos ja terves asendis. Ta ei tõsta kohutavat kisa nagu Vergilius oma Laokoonist laulab: suu oma avatuses ei luba seda. /---/ Keha valu ja hinge suurus on terve kuju ülesehituse kaudu sama tugevusega välja jagatud, justkui kaalutud.“"35

Sama palju kui valgussajandit võib käsitleda mõistuse sajandina, on see emotsioonide aeg, mis selgele seab vastu ebamäärase, utoopilisele tuleviku ihalusele valu kaotatud mineviku pärast, mis oli inspireerinud poeete juba alates John Donne ist John Miltonini. ${ }^{36} \mathrm{Ilu}$ ja valu on ühe ja sellesama medali kaks vastandpoolust. Nende ühiseks nimetajaks võib pidada ülevat ja melanhooliasegust igatsust kaotatud paradiisi järele, mis väljendub nii üleva õuduse ja hirmu kui ka kunsti läbi aegade saatvas pürgimuses positiivse ilu ja hüve järele. Ka kõige hirmsamas tõehetkes, kus kunstnik näib olevat kaotanud viimase lootuse, sisaldub negatiivi kujuteldava vastandpoolusena õnne puudutus, mis pimedusele vastandab valguse. Olgu

31 Edmund Burke, A Philosophical Enquiry into the Origin of Our Ideas of the Sublime and Beautiful (London: Vernor and Hood, 1798), 58.

32 Alex Potts, Flesh and the Ideal. Winckelmann and the Origins of Art History (New Haven, London: Yale University Press, 2000), 111, 127.

33 Johann Joachim Winckelmann, Gedanken über die Nachahmung der Griechischen Werke in der Malerei und Bildhauerkunst, Erste Ausgabe 1755 mit Oesers Vignetten (Stuttgart: G. J. Göschensche Verlagshandlung, 1885), 19

34 Jonathan Richardson (vanem), An Essay on the Whole Art of Criticism, as it Relates to Painting and an Argument in Behalf of the Science of a Connoisseur (London: Pater-Noster Row., 1719).

35 Winckelmann, Gedanken über die Nachahmung der Griechischen Werke in der Malerei und Bildhauerkunst, 24.

6 Erin Sullivan, Beyond Melancholy. Sadness and Selfhood in Renaissance England (Oxford: Oxfor University Press, 2016), 2 jj. 
siis tegemist apokalüptiliste Viimse kohtupäeva stseenidega Jan van Eycki või Hans Memlingi maalidel või tükkideks raiutud loodusega, nagu seda kogeme läbi Damien Hirsti teosel „Mother and Child (Divided)“ (1993). Ka negatiivne religioon juhatab meid tagasi usulise kogemuse juurde, nagu sellest kirjutab Jacques Derrida. „Usk ilma usuta on otsus otsustusvõimetuses, kus otsustusvõimetus on usu koostisoas, mitte usu vastand, vaid selle element. ${ }^{\prime 37}$ Kättesaamatu unistus inimkonna õnneliku lapsepõlve järele kätkeb endas leinameeleolu, ${ }^{38}$ tehes võimalikuks näha kultuuri selle eneseteadvuslikult tagasivaatavas sügavuses.

Winckelmann suutis anda inimvaimule täiesti uue asjade vaatlemise viisi. ${ }^{39}$ Oma ajastu lapsena, on tema retoorika kultuuriliseks taustaks nii mõistuse sajandi kutse kui ,geeniuse ajastu“ ${ }^{40}{ }^{40}$ mis toob klassika objektiivse kaanoni varjust esile indiviidi romantilise tundeelamuse, võimaldades meil universaalse kõrval kõneleda erilisest, kunstiteosele omasest võimest sünnitada emotsioone ja kirgi. Unustades klassikalise ilu lahutamatuks saatjaks oleva üleva, välistame võimaluse mõista nii ajastut kui kunsti, mis kujundi - eidoloni loomisel on mõlemad olevana kohal. Neist ühe või teise puudumine tähendab olukorda, kus me ei saa kõneleda teosest selle terviklikkuses. Kunsti sünniks vajab kunstnik nii ülevat hinge kui teadmisi maailma kohta, mis ajale ja ruumile annavad selle hinge ja värvi.

\section{LESSING JA LUULEKUNST}

Winckelmannist erinevana ei ole Lessing kunstnik, ega ka mitte kunstiajaloolane, vaid literaat ja intellektuaal, kellele sile marmor tähistab ilu vangipõlve. „,Laokoon on sümmeetria ja mehise vormi musternäide /---/ äratades tundeid ja kirgi, tasandades neid ometigi graatsia abil. Kas aga sellest piisab tõeliseks kunstielamuseks? Kas ei takista kaunis vorm meil saamast osa Laokooni kõige sügavamatest kannatustest?" ${ }^{\prime 41}$ Valeva marmori asemel otsib Lessing kunsti kõrgemaid tasandeid vaimu vallast, kuhu küündivad vaid luuletajad. „Kuidas küll oleks võimalik

37 John D. Caputo, The Prayers and Tears of Jacques Derrida. Religion without Religion (Bloomington, Indianapolis: Indiana University Press, 1997), 62.

38 Davis, „Winckelmann Divided: Mourning the Death of Art Histroy“, 21.

39 Georg Wilhelm Friedrich Hegel, Vorlesungen über die Ästhetik, Bd. I (Frankfurt am Main: Suhrkamp Verlag, 1970), 92.

40 Erik Forssman, Goethezeit: Über die Entstehung des bürgerlichen Kunstverständnisses (München, .

41 Lessing, „Laokoon ehk maalikunsti ja poeesia piiridest“, 413. kirjeldada Laokooni huulilt vallanduvaid metsikuid hüüdeid, mis vallandusid Sophoklese „Philoktetese“ ette kandmisel? Ah! Ah. Oh! Häda häda mulle, terved read täis valu- ja hädakiljatusi, mida tuli deklameerida hoopis teistsuguse kestuse ning pausidega, kui see on viisiks tavalises seotud kõnes. /---/ Poeesia on avaram kunst, poeesias on võimalik selline ilu, mis maalikunstis iialgi saavutatav ei ole. ${ }^{\prime \prime 2}$

Ilusa kõrval ei paku maalikunst lihtsalt võimalust kujutada kõrvalekaldeid, seal hulgas näiteks hirmuäratavat ja inetut, mille puhul poeedile on võrreldes maalikunstnikuna vaba voli. Selles mõttes on kunsti piirid ahtamad, vaid luule väljub kaanoni kontrolli alt, eristudes ülejäänud kunstidest oma vabadusega kujutada mitte ainult nähtavaid, vaid ka nähtamatuid asju, mõõdetava kõrval mõõdetamatut. Lessingi väitel suudab maalikunst kujutada üksnes kehalist ilu, mis vanadel kreeklastel oli kunstide ülimaks seaduseks. ${ }^{43}$ Maalikunstnik võib liikumist ainult aimata lasta, kuid tegelikult on tema figuurid liikumatud. „Maalikunstnikul on täiesti võimatu jumalat sellises erakordses suuruses kujutada. Kui ta aga seda ei tee, ei lama maas Homerose Mars, vaid tavaline sõdur." ${ }^{\prime 44}$ Poeesia seevastu on võimeline kujutama ka kõige kõrgemaid ideid. Maalikunst suudab kujutada kehalist ilu, luule seevastu hingelist.

Lessing ei usu pildi võimu anda edasi inimese kõige sügavamaid tundeid. Tema lähenemises kujundile kõlab sajandite pikkune ikonoklastiline eitus, mis on saanud toitu aastatuhandete vanusest pildieitusest, vastandades Kreeka inimnäoliste ja kehaliselt kaunite jumalate idee kristliku tõe nähtamatust ja kehatust vaimust. Lessingi sõna võimus pildi ees kõlab kaasa visuaalse suhtes kahtlev protestantlik noot. Selle kandjaks sai valgustusajastu domineeriva kunstilise lähenemise klassitsismi raames avalduv protest nii baroki dramaatilise paatose kui rokokoo meelelisuse vastu. Ühel või teisel moel kanname ikonoklasmi varje südames tänaseni. Meis elav kahtlus kehalise ilu vastu ei luba meil tunda täit naudingut kehast kui kunstilise inspiratsiooni allikast ja sellele omasest kõige suuremast ilust (kr kallisteia). Eitus kujundi ja selle kaugemaks kutseks oleva üleva vastu, toob meelde Bütsantsi kristlikud keisrid, kes kartes kreeka kujudele omast sisemist energiat, lasid need tõugata merre või siis võtta need lahti üksikosadeks. Konstruktsiooni asemel, mis oli omane möödunud modernismi ajastule, on sellele järgnenud postmodernismi lipukirjaks

42 Lessing, „Laokoon ehk maalikunsti ja poeesia piiridest", 333, 367

(1) 
pigem dekonstruktsioon, vastumeelsus traditsioonilise esteetika ja kogu kreeka kunstile iseloomuliku täiusliku ilu - kalokagathia vastu.

See muudab kunstist kõnelemise päev-päevalt üha keerulisemaks - muutes kunstiajaloo kui mitmekülgse ja emotsionaalselt rikka diskursuse osaks teadusliku mõtlemise analüüsi ja sünteesi kesksest lähenemisest ning välistades määratlematud kategooriad (nagu ilu, tundeelamus, rõõm, kurbus ja meeleheide) professioonile omasest leksikast. Winckelmanni kuju armastuse asemel oleme valinud Lessing kahtluse kuju võimu vastu, reserveerides meie sügavamate tunnete kirjeldamisel koha sõnale, unustades lihtsa ja juba artikli alguses esile tõstetud tõsiasja, et mõlemad neist suhtlevad maailma ja seda väljendada üritava tõega mitte otse, vaid vahendatuna läbi ettekujutuste, fantaasia ja unenägude. Mõlemad neist on absoluutse tõe suhtes relatiivsed, tuletuslikud ja võivad ka seetõttu petta.

Just seepärast ongi soovitav kunsti usaldada. Vaadata maalikunsti avatud silmadega ja kuulata luuleteost muusikaliselt häälestatud kõrvaga. Nii nagu loodus, seisab ka kunst lähedal vaimule, maise ilu kõrval on selle kvaliteediks vaimne ilu, olenemata, millised reeglid talle kehtestame ja millisel ajahetkel sellega suhtleme, kannab endast tarvet suhelda millegi suurema ja pühaga. Hetkel, mil kunst leiab koha vaimus, on see astunud üle nähtamatu läve, mis muudab tavalise fakti kunstiteoseks, mille äratundmiseks vajame ennekõike katarsislikku elamust, mis lubab mimeesise poolt vahendatud välisel saada osaks meie sisemisest maailmast ja anda tõuke uue kunstilise reaalsuse sünnile. Paljude teiste eesmärkide kõrval on kunsti ülimaks kutseks leida side esteetilise ja eetilise vahel, väljendada seda, millest kirjutas juba Platon ja mis Plotinuse järgi inspireerib kunstnikku leidma oma teoste kaudu üles valguse, millest ühel või teisel viisil kirjutavad nii valgustusajastu kunstiteoreetikud kui kõik teised, kes on üritanud kunsti defineerida.

\section{HERDER JA ÜRGMETS}

Herder, kes kirjutas Laokoonist inspireerituna ligemale kolmesaja leheküljelise teose, kiitis selle eessõnas Winckelmanni tema kauni keele eest ja tunnustas teda antiikkunsti erudeeritud eksperdina. Vähendamata seejuures Lessingi kaalu literaadi ja poeedina. Tuues oma „Kriitliste metsade“ esimeses osas ära pika tsitaadi Winckelmanni Laokoonist (seda küll pisut muudetud kujul) andis Riias Jakobi kirikus pastoriametit pidanud ja hilisem Goethe mõttekaaslane õiguse mõlemale poolele - Winckelmannile kunstide vallas ja Lessingile luulekunsti prohvetina. „Lessing tõstab tõe esile hinge sügavustest, kas peaksin seepärast pidama tema arvamusi spekulatiivseks, pigem on ta vaimukas; ja kui ta mõningal juhul läheb liigagi kaugele oma arvamustes, kas peaksin seepärast arvama, et ta ei ole muud kui mõistatuste esitaja? ${ }^{\prime 45}$ Ka Herderi enda huvi keskedub sõnale, mida ta jälgib filosoofile omase sügavmõttelisusega ja mis paljuski mõjutas tema järglasi nende lingvistilistes otsingutes sõna algsete tähenduste üle. Visuaalne esteetika, millest Herder küll oma Laokoonile pühendantud teost alustab, näib teda puudutavat suhteliselt vähe, üksnes sedavõrd, kui see on kooskõlas tema otsingutega filosoofia ja keeleteaduse vallas.

Võrreldes kahe eelmisega, oli Herder Köningsbergis Kanti õpilasena leidnud varakult tee Alexander Baumgarteni esteetika õpetuse juurde, nimetades viimast koguni Saksa uue ajastu Aritoteleseks. ${ }^{46}$ Seda küll pigem tema mõtteteravuse ja uudsuse kui vaadete sarnasuse tõttu Aristotelese mõtetega. Enam kui sellest ehk täna armastatakse kõneleda, oli Herder avatud spirituaalsele kogemusele, mida vahendasid nii Gottfried Wilhelm Leibnizi kui Christian Wolffi ja Hamanni seisukohad, mis tõstsid esile metafüüsilise Jumala rolli tervikliku inimtunnetuse loojana. Herderi abstraktse tundefilosoofia keskpunktis on inimesele antud eneseväljendamise süvaprobleemid ja sellega kaasnev huvi subjekti võime kohta leida vastus eksistentsi kõige olulisematele ja vastuolulisematele küsimustele. Kunstiteos ei ole üksnes mõte ega ka keha, vaid eriline seisund, mille läbi tunded kohtavad mõistust ja ebaselgetest ideedest kujunevad selged sõnad ja mõisted. Herderi järg „põhineb meie arusaam maailmast mitte niivõrd asjadel, kui nende tähendustel, võimaldades teha vahet naturaalsel ja kunstilisel esteetikal - looduse ja kunsti ilul, mis erinevad teineteisest üksnes nende selguse astme poolest; ja seda isegi sel juhul, kui nad on teineteisele põhjuslikuks eelduseks ${ }^{\prime \prime}{ }^{47}$ Geeniuse ülesanne on tuua esile ilu, mis peitub nii

45 Johann Gottfried Herder, Kritische Wälder. Oder Betrachtungen, die Wissenschaft und Kunst des Schönen betreffend, nach Maasgabe neuerer Schriften, Erstes Wäldchen (Riga: Bavarian State des Schönen betreffend, nach Maasgabe neuerer Schriften, Erstes Wäldchen (Riga: Bavarian State
Library, 1769), 13.

46 Gregory Moore, ,Introduction“, Selected Writings on Aesthetics, ed. by Gregory Moore (Princeton Princeton University Press, 2006), 2.

The Arts". Tsiteeritud: Howard, Laokoon. Lessing Herder, Goethe. Selections, 190 
looduses kui kunstis, kuid mis avaneb ainult teatavates tingimustes spontaanse loomingulise tegevuse vahendusel.

Nii nagu Lessing, teeb ka Herder panuse sõnale. „Keele leiutamine on inimesele sama loomulik kui inimeseks olemine. “48 Jäädes truuks oma kirjanduslikele eelistusele, seab Herder luulekunsti kujutavast kunstist kõrgemale. „Mida ma kunagi kord õppisin Homeroselt, on, et luulekunst on juba eesmärkide poolest energilisem kui pilt ja maal ka oma kõige sügavamas hingetõmbes. Õppisin Homeroselt, et luulekunst ei puuduta oma tonaalsusega mitte ainult meie kõrva ja selle kaudu mõtet, vaid hingelisi otsinguid, äratades fantaasia, mida ei ole võimalik mitte iialgi välja arvutada. ${ }^{49}$

Sõna kaudu mõistame mitte ainult seda mida näeme, vaid ka seda, mida me sõna otseses mõttes ei näe, mis ei ole selge ega piiritletud, vaid ähmane ja selgusetu. Jutustades loo üksikule saarele eksinud pimedast inimesest, kes teda ümbritsevat tuhandet imet oli võimeline kogema looduse häälte järgi, kirjutab Herder: „Värisevad puulehed tõid kaasa jahedust, mööda vulisev oja kiigutas unes, kahisev läänetuul puudutas ornalt palet. Vaguralt määgiv lammas andis piima, külluslik oja vett mühisev puu vilju /---/ ka ilma neid kõiki nägemata, oli ta oma hinges valmis ümbritsevat selle täiuslikkuses tundma õppima." ${ }^{\text {"50 }}$

Meie tajud vahendavad meile väliseid fakte, luues nende põhjal ettekujutusi, mis kujundite kaudu pakuvad luuletajale võimaluse sepistada värsse ja kunstnikule luua pilte. Andes prioriteedi sõnale, leiab Herder koha ka kõigile teistele kunstidele. Igal kunstiliigil on seejuures omad hieroglüüfid, põhimõtted ja sümbolid, nagu sellest juba paarkümmend aastat varem kirjutas Diderot. ${ }^{11}$ Kunsti poolt loodud sümboolne ja terviklik maailm, mis on sama palju ebaselge kui selge ja milles inimene vaatamata kõigile pingutustele, ei ole võimeline jõudma üheste ja lõpuni mõistetavate otsustusteni. ${ }^{52}$ Seejuures ei ole aga sõna ainus ega koguni mitte lõpuni domineeriv vahend. Kõikide kunstiilmingute vahel valitseb sugulus. Nii nagu keel ja luule, pürgivad kunstid üha kõrgemale tasemele, mis vabanedes neile loomuomaselt omasest barbaarsusest, juhatavad inimese läbi kaunite kunstide (beaux arts) ja valitud kirjasõna

48 Tsiteeritud: Howard, Laokoon. Lessing, Herder, Goethe. Selections, 148.

49 Johann Gottfried Herder, Kritische Wälder. Oder Betrachtungen, die Wissenschaft und Kunst des Schönen betreffend, nach Maasgabe neuerer Schriften, Erstes Wäldchen, 230-231.

50 Herder, Abhandlung über den Ursprung der Sprache: Welche den von der Königl. Akademie der Wissenscahaften für das Jahr 1770 gesezten Preis erhalten hat, 159.

1 Denis Diderot, Kirjast Batteaux'le 1751. aastal. Tsiteeritud: Howard, Laokoon. Lessing, Herder Goethe. Selections, IX.

Jottfried Herder, „On Image, Poetry and Fable“, Selected Writings on Aesthetics, ed. by Gregory Moore (Princenton: Princenton University, 2006), 355. (belles lettres) ilu mõistmiseni: „Noore mehe, kelle hinges suigub ilufilosoofia, äratab kunstigeenius oma võimsate ja suurejooneliste ideedega, mis toob ta tema sisemise pühamuni, mil ta näeb ehitist ja õpib teda imetledes tundma maailma. Näen sind sügavasse mõtisklusse vajumas, kui sa kogud end pärast esialgset muljet võimust, jõust ja ülevusest, kui sa õpid tundma ehitist, seda igavest monumenti, mis kestab aastasadu ja terveid inimeste rasse, õppides neid tundma nii nende ühtsuse mitmekesisuses, kogu neile omases lihtsuses, mis väljendab end kõige ülevamas korras, andes tunnistust nii reeglipärasest sümmeetriast kui kombekohasest maitsest." ${ }^{\text {53 }}$

Ilu kui idee eksisteerib enne subjekti, tähenduse sellele annab aga subjekti võime luua kujutluspilte, mis avavad hinges metafüüsilise akna, mille kaudu mõistame maailma ja iseennast läbi metafooride salapärase keele, „mis ükskõik siis, kas teadlikult või alateadlikult unistab ja poetiseerib lõputult /---/, kõige selle kaudu saavad ilmsiks nii loodus ku

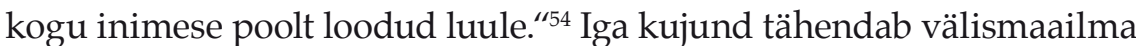
esindatust. „Kui see on kehaline, siis on see nähtav kujund. Kui see on esitletud minu kujutlusvõime kaudu, on see fantaasia, mis vaatamata kõigile laenab oma seadused nähtavatelt objektidelt. Esimesel juhul olen ma ärkvel, teisel juhul näen und; ja saame tõdeda, et inimene võib häirimatult unistada isegi siis, kui ta ei maga. ${ }^{455}$ Lähtudes Winckelmannist, tuletab Herder oma kujutava kunsti puhul kehtivad põhimõtted ideaalse ilu printsiibist, mis saanud küll alguse loodusest ületab seda ja mida sügavamas mõttes võivad tajuda need, kellele on antud võime tuua välisest vormist esile sisemine ilu. Nii tugineb Herderi esteetika neoplatonistlikule arusaamale, mille puhul meist igaüks ,just nagu skulptor tehes kuju, mis peab ilus olema, raiub midagi ära, tasandab midagi puhtaks, kuni on kujule andnud ilusa välimuse. ${ }^{456}$ Kunsti mõistmiseks vajab inimene kaemuslikku hingeredelit, mille hüpostaase pidi kõrgemale tõustes oleme võimelised tunnetama lõplikku ja ainumat. ${ }^{57}$ Selleni juhatab inimese kontemplatiivne mõtiskelu ja kunst kui selle üks väljendusvorme.

53 Johann Gottfried Herder, „Kritische Wälder. Oder Betrachtungen über die Wissenschaft und Kunst des Schönen“, 1769, Herders sämmtliche Werke, Bd. 4, hrsg. von Bernhard Suphan (Berlin: Weidmannsche Buchhandlung, 1878), 155. 54 Ibidem.

55 Herder, On Image, Poetry and Fable, 358. Siin kordab Herder Platoni mõtet piltidest, mis on inimese (kunstniku) poolt loodud unenägudest neile, kes on ärkvel (Platon, Sofist 226C).

56 Plotinos, ,Ilust:

by James Hankin 
Kunsti kaudu sünnib uus reaalsus, mis muudab olemasoleva reaalsuse (realità existenziale) nn puhtaks reaalsuseks (realità pura $)^{58}$, millekski, mis küll sarnaneb meie silma ja meelte kaudu antud ning aru läbi korrastatud maailmaga, mis aga sellest erineb - niisamuti kui argielu erineb unenägudest, jättes sideme pildi ja minu vahel lõpuni välja joonistamata. Kvaliteedi kõrval, mis prevaleerib teose vormis, on kunstile omane kvaliteet, mis lakkamatu igatsusena täiuslikkuse järele, toidab meie unistusi ja „mille kaudu meie sensitiivne loomus loob eelduse võimele kujutada ette ülemeelelist ja seda absoluutselt kõikide suurte asjade võrdluses.“59

Mõistmata üht, ei saa me aru teisest. Väljendagu see siis kahe väljendusviisi, luule ja maalikunsti, vahelistes seostes või ka ühes ja ainumas teoses. Laokooni silmitsedes kõneleb temas nii Euroopa aastatuhandete pikkune kultuur ja sellele omane ajalooline mälu, kui veel teine ja olulisem mälu, mida Paul Ricœur on käsitlenud fantaasiana. ${ }^{60}$ Mis on kohal nii teose eostamise hetkel kui ka siis, mil idee alles otsib endale vormi ja pungast tõotab puhkeda õis. Juba ammu enne on alati ja kusagil midagi, mille res cogitans on selle läbi meie tunnetuse muutnud tegelikuks. ${ }^{61}$ Kunsti kaudu kompame piire. Ja kõigepealt omaenese tunnetusvõime piire, mis Benedetto Croce kohaselt võivad omada kahte erinevat vormi: intuitiivne ja loogiline; tunnetust saab teostada kas fantaasia või intellekti kaudu, olla individuaalse või universaalse tunnetus, niisiis võib luua kujutluspilte (immagini) või mõisteid (concetti). ${ }^{62}$

\section{KUNSTIAJALOOLANE GOETHE}

Erinevalt oma kaasaegsetest literaatidest oli Goethe nii luuletaja, kunstnik kui ka kunstiajaloolane, kelle otsustused kunstieksperdina, kes saanud innustust küll Itaalia reisidelt, nägi paljuski antiiki läbi Winckelmannilt laenatud silmade..$^{63}$ Goethe kõneleb metafooridest sädelevas keeles. Tema Laokoonist kõnelevas teoses, mis ilmus ligemale kolmkümmend aastat

58 Paul Philippot, „The Phenomenology of Artistic Creation according to Cesare Brandi“, Cesare 59 The Sublime. From Antiquity to the Present, ed. by Timothy M. Costelloe (New York: Cambridge University Press, 2012), 55.

60 Ricour, Memory, History, Forgetting, 11.

61 Umberto Eco, Kant and the Platypus. Essays on Language and Cognition (Boston: Houghton Mifflin Harcourt, 2000), 18

62 Benedetto Croce, Esteetika kui väljendusteadus ja üldlingvistika. Teooria ja ajalugu (Tartu: Ilmamaa, 1998), 29.

63 Detlev Kreikenbom, „Goethes Anschauung Antiker Kunst", Goethe und die Kunst, hrsg. von Sabine Schulze, Ausstellung Schirn Kunsthalle Frankfurt, 21. Mai 1994-7. August 1994 / Kunstsammlungen zu Weimar, Stiftung Weimarer Klassik, 1. September 1994-30. Oktober 1994, (Ostfildern, 1994), 40. hiljem kui Lessingi samanimeline kirjutis, astub esile elutark ja kunstiga aastaid sõbrustanud erudiit, kelle pilk on suunatud kaugemale kui ehk kõigil eelnevalt Trooja preestrist kirjutajatel ja kes seda, mis paljudele teistele sünnitas lahendamatuid probleeme, oli võimeline hindama lepitavalt tolerantsena. Goethe jaoks ei tekita sõna ja maalikunsti vastandlik suhe probleeme; kunsti sisemine olemus eksisteerib väljaspool ühe võ teise konkreetse žanri või meetodi piire. Meist igaühel on õigus nähe teost omaenese silmadega. Ja mis veelgi olulisem - „kui kuju peale restaureerimist jälle välja pannakse, võib iga austaja sellest rõõmu tunda ja sellest omaenda viisil kõneleda." ${ }^{" 4}$

Laokooni ees on sobiv seista suletud silmadega, et hetkel kui avada silmad, olla valmis nägema marmorit selle liikumises. „Võin teile kinnitada, et nii nagu kuju täna seisab teie ees, meenutab see välgusähvatust, tõusvat lainet, mis kivistub meie silme all, põrkudes vastu kallast. See on mulje, mis kinnistub, kui näeme kuju öösel tõrvikuvalguses." ${ }^{\text {" Iga }}$ hetk on ainulaadne. Iga kord teosele otsa vaadates näeme seda uuesti. Oma olemuselt on kunstilised kujundid enesesse sulgunud (durch und in sich geschlossen ${ }^{66}$ ), samasugused kui sõnad, mille ürgne tähendus jääb meile igavesti mõistetamatuks. „Tõeline kunstiteos, nagu iga looduse teos, jääb meie mõistusele alati lõpuni mõistetamatuks, teda vaadeldakse, ta äratab tundeid, ta mõjub, aga teda ei saa kunagi päris lõpun tunda, veel vähem tema olemust mõista, tema teenet sõnadesse panna." ${ }^{\text {"6 }}$

„Kõigi muude tunnustatud teenete kõrval on Laokooni grupp nii sümmeetria kui mitmekesisuse, nii rahu kui liikumise, nii vastandlikkuse ku erinevate impulsside kokku sulamise näidiseks, mis ennast koos, osaliselt tunnete kaudu ja osaliselt vaimselt, vaatajale näitavad ning mis äratavad ettekujutuse kõrgelennulisest paatosest kantud meeldivast tundest, pehmendades kannatuste ja kirgede tormi läbi graatsia ja ilu. ${ }^{\text {"68 }}$ Kunstiteose sisu määrab sisemine võime sünnitada vaatajas ärevuse ja äratundmise tunne, mis teeb kunstist kunsti ja loovast aktist sündmuse, avab meile võimaluse näha faktidest sügavamale. Kunstiteose mõistmisel on olulised silmad ja temast kõnelemisel keel ja sõnad. Luues teosest kujutluspildi, on võimalik asuda meie arvamusi teose kohta struktureerima ja süstematiseerima, kasutades selleks Goethe enda poolt kunstiteose hindamiseks välja pakutud mõisteid: elav ja kõrgelt organiseeritud loodus

64 Goethe, Über Laokoon, 3.

65 Ibidem, 5.

66 Ibidem, 6 .

67 Ibidem, 3.

68 Ibidem, 6 
(Lebendige, hochorganisierte Natur), karakter (Charaktere), rahu ja liikumine (in Ruhe oder Bewegung), ideaal (Ideal), veetlevus (Anmut), ilu (Schönheit). ${ }^{69}$ Seejuures on Goethe kaugel soovist normeerida ja hierarhiseerida, mis aitaks leiutada kunstikirjutise tarvis ühise ja kõiki osapooli rahuldava võrrandi. Nii nagu elu, on ka kunst täis konflikte, üleminekuid ja kompromisse vormilise ja hingelise, materiaalse ja vaimse vahel.

„See jääb minust kaugele, et peaksin eraldama inimliku loomuse ühtsuse, et peaksin salgama selle suurepäraselt haritud mehe vaimu jõudude kaasaaitamist, et peaksin mitte mõistma ühe suure loomuse püüdlusi ja kannatusi. Mulle tundub ka, et hirm, kartus ja ehmatus, ning isalik sümpaatia voolavad nendes soontes, tõusevad selles rinnas, kipruvad laubal; hea meelega tunnistan, et nii tundeline kannatus kui ka vaimne kannatus on koos kõige kõrgemal tasemel esitatud.“汭 Nii nagu loodus ei mõõda aega ega loe kokku meetreid, kilomeetreid või staadioniringe, vaid on alalises muutuses, on ka kunst kui geeniuse looming täiuslik oma valitud vormis, eeldades siiski, et keegi seda vaatab ja laseb ennast sellest kaasa kiskuda. Kunstiajaloolase roll algab hetkest, mil kunstnik on otsustanud oma teose üle anda vaatajale, sellest ise kaugenedes, kinkides tema poolt loodud väikese maailma suurele maailmale, lootuses muuta see paremaks ja täites sellega ülesande, mille kaugemaks eesmärgiks on tõsta meid ühest maailmast teise. Kunsti eristab elust pühendumus. Seda isegi juhul, kui me seda sõna otseses mõttes ei oska määratleda, vaid tunneme üksnes oma veres ja lihas. ${ }^{71}$ Küsimuseks, millele seejuures on üritatud läbi aegade vastata - kuidas seda kõike valdavat tunnet, mis haarab meid kunstielamusena, ära seletada viisil, mis jätab alles teose ja ometi puudutab meis elavat tahet leida võimalus selle käsitlemiseks seostes paljude teiste kunstifaktidega - nii meie enese kunstitahte kui maailmaga kunsti ümber.

\section{ILU JA ÜLEV}

„Maailm, mida näeme, ei ole tühjus ega ka aine, vaid midagi muud, mis „optilise plasma“" kujul täidab tühjuse asjade vahel," väidab Aristoteles. ${ }^{72}$ Kujundid, mille oma teadvuses loome on kahekordne peegeldus, mida

\section{Goethe, Über Laokoon, 4.}

70 Ibidem, 9 .

71 Melissa McBay Merritt, „The Moral Source of the Kantian Sublime“, The Sublime. From Antiquity

to the Present, ed. by Timothy M. Costelloe (New York: Cambridge University Press, 2012), 43.
72 Aristotle De Sensu and De Memoria: Text and Translation with Introduction and Commentary, ed. by George Robert Thomson Ross (Cambridge: Cambridge University Press, 1906), 2, 438. aitavad meile vahendada meie meeled: silmad, kõrvad, nina ja suu. Nägemine kujutab endast akti, mille puhul valgus on saavutanud läbipaistvuse ning on sütitanud tule, mille puhul läbipaistvus ei ole enam mitte potentsiaalne, vaid aktuaalne, muutes kehad, mis on vaatlejast eraldatud läbipaistmatu kihiga nähtavaks. ${ }^{73}$ Väline annab meile endast teada läbi meis üha uuesti sündiva kujundite rea, mille kohta on ikka ja jälle küsitud, kuidas leiab lõputult mitmekesine ja sageli vastuoluline maailm koha meie abstraktses teadvuses, pannes aluse mõistetele, mis ettekujutuselt juhatavad meid mõistmise poole..$^{74}$

Olemus ja olemine (ld esse ja essentia) sulavad inimese teadvuses ühte. Meie eksistentsi sügavama olemuse moodustavad ettekujutused, millest ise trükime välja kujutluse. ${ }^{75}$ Mimeetilist protsessi ennast ei ole seejuures aga suutnud keegi veel ära seletada. Kõige laiemas tähenduses on kogu maailm kunstiteos, mille autoriks on meis elav individuaalne geenius ja mis ilmub meie kollektiivses teadvuses nii arvutu hulga üksikfaktidena kui laiemate mõistetena - olgu selleks siis näiteks maastik, veetlev naine, Heliose vanker, mis tõuseb taevasse Parnassose mäelt. Kuidas küll oleks neid võimalik seletada mingis muus keeles kui seda pakub kunst? Kunst jääb kunstiks ka siis, kui loobume soovist seda ära seletada.

Tark kunstiajalugu on seda alati teadnud ja suunanud oma tähelepanu pigem kontekstile ja teost ümbritsevatele sündmustele - sotsiaalsetele olukordadele, kunstniku biograafiale, värvipigmentidele ja tehnilistele lahendustele. Kunstiajalugu, nagu seda täna tunneme, on moodsate aegade fenomen par excellence, mis on sündinud 16. sajandil, üritades matta ammuse problemaatika nägemise ja kujundi kohta mimeetilise mõistmise ja ikonoloogilise loetavuse ülemvõimu alla. ${ }^{76}$ Nii nagu igal teisel teadusdistsipliinil, on ka kunstiajalool oma raamid. Kui Lessing võtab ülesse teema luule ja maalikunsti piiridest, siis kirjutab ta tegelikult kunstiajaloo kui meetodi piiridest, andmata endale ehk lõpuni aru, mis siis on pilt ja kuidas see on võimeline mõjuma meie tunnetele. Ja kas tundeid on võimalik ära seletada? Või väljenduvad need lõppude lõpuks üksnes läbi meie kõige sügavamate ja tõele lähedasemate hüüa-

73 David C. Lindberg, Theories of Vision from Al-Kindi to Kepler (Chicago, London: University of Chicago Press, 1976), 7.

74 Paul Guyer, „Introduction“, The Companion to Kant's Critique of Pure Reason, ed. by Paul Guyer (New York: Cambridge University Press, 2010), 15

75 Kant Immanuel, Kritik der reinen Vernunft, I Buch, II Hauptstück, hrsg. von Jens Timmermann (Hamburg: Felix Meiner Verlag, 1998), 232.

76 Georges Didi-Huberman, Confronting Images. Questioning the Ends of a Certain History of Art (Philadelphia: Pennsylvania University Press, 2005), 8. 
tuste: „Ohh, ahh, häda mulle!“ Mida luuletaja üritab vormida värssideks ja maalikunstik kujunditeks ja neid moodustavateks joonteks ja värvideks. Mis lõppude lõpuks ei ole midagi muud, kui meie enda poolt loodud ettekujutused, millel on küll side ümbritseva kõiksuse ja loodusega, aga ometigi meie eneste loodud.

See, kes üritab pääseda kunstist kirjutades sügavamale ja kõneleda mitte ainult tagajärgedest, vaid ka loomingu põhjustest, teeb seda oma vastutusel. Kui minult küsitaks, kuidas peaks kirjeldama Laokooni või kirjutama näiteks Eesti kunstiajalugu, jään vastuse võlgu. Malbelt ja targalt, nagu seda Winckelmannile viidates, on ikka ja jälle korratud. Mille puhul jääb kunstiajaloolase ülesandeks eristada erinevaid perioode ja kunstistiile. Või siis siduda kunstifaktid ühiskonnas aset leidnud muutustega. Vaid „hull“ üritab väljendada tundeid, mida kunstiteos meis esile kutsub, manades silme ette midagi, mis jääb sõnades väljendamata ja millest võib kõneleda vaid afektiivses tunnete keeles. „Kunsti loob geenius, esteetilisi ideid kujutav mõiste.“"77 Kanti järgi on esteetiline idee ettekujutus, mis koosneb nii eripalgelistest üksikkujutlustest, nii et nende seast pole võimalik leida ühtegi kindlale mõistele viitavat väljendust, ja mis lisab seetõttu mõistele suuresti seda sõnuseletamatut, mis elavdab tunnetusjõudu ning lisab keelele, selle pelgale kirjatähele, vaimu. ${ }^{78}$ Oma olemuselt sarnaneb kunst luulega, mis nagu üldiselt teada, ei vasta lähenemisele, mida oleme harjunud siduma teadusega. „Geeniust konstrueerivad elemendid on niisiis kujutlusvõime ja intellekt (ehk aru - Verstand); geenius seisneb õnnelikus oskuses - mida ei saa õppida üheltki teaduselt ega omandada kui tahes suure usinuse abil - leida ideid antud mõiste tarvis ning tabada väljendust, mille kaudu saaks nõndaviisi sündinud subjektiivset meeleliigutust kui mõiste saatjat teistele edasi anda.“79 Mille sõnalised allikad on kinni pigem taas korra kunstilises kujundis ja sellele omastes praktikates, mis Heideggeri järgi võimaldab meil „oleva varjamatuse lausumusena“ näha pealispinnast sügavamale „nõnda, et sõna alles tõeliselt sõnaks muutub ja jääb“.80

Nii Winckelmann, Lessing, Herder kui Goethe, keda olen suurema ja vähema julguse ning järjekindlusega käesolevas essees tsiteerinud, tead-

77 Croce, Esteetika kui väljendusteadus ja üldlingvistika, 322.

78 Immanuel Kant, Otsustusvõime kriitika, 1790. Tsiteeritud: Croce, Esteetika kui väljendusteadus ja üldlingvistika, 322 .

dus ja üldling
79 Ibidem.

80 Martin Heidegger, Kunstiteose algupära, tlk Ülo Matjus (Tartu: Ilmamaa, 2002), 46. sid midagi, mis tänases kunstimaailmas (art world) on läinud kaduma või elab kusagil kunstifilosoofia hämaras metsas, peavoolu ehk siis mainstream'i kõrval. Millest kõneleb fenomenoloogiline lähenemine ja mille algprintsiip - suhelda mitte objektiivsete faktide, vaid neid peegeldavate subjektiivsete ettekujutustega, on eelduseks „parergon'i eraldumiseks ergon' ist (teosest) ${ }^{\prime \prime 1}$, mille puhul kujund eraldub kõigepealt teda põhjustanud taustast ning hakkab seejärel elama omaenese kunstiteosele omast elu.

Teose mõistmiseks on mitu erinevat algust. Üheks võimaluseks on tulla tagasi Winckelmanni juurde, kes tõeliselt ilusale (Wahrhaftig Schöne) vastandab veetleva (das Liebliche), tuues esile üleva tunde (erhabene), mis tõuseb esile hetkel kui puutume kokku harmoonia ja suursugususega (Harmonie und Grossheit), ja igavese iluideaaliga. ${ }^{82}$ Tõsi, „,kunst võib kujutada ka loomuldasa inetuid asju, kunstiline asi pole ilus asi, vaid asja ilus ettekujutus; siiski on inetuse kujutamisel igas kunstis omad piirid (Lessingi ja Winckelmanni mõjul) ja lisaks veel absoluutne piir vastiku ja jälgi näol, mis tapab kunstilise ettekujutuse kui sellise. ${ }^{\text {" } 33}$

\section{KOKKUVÕTTEKS}

Mäletades Winckelmanni ja 18. sajandil puhkenud diskussiooni Laokooni üle, ei piisa ainult ühest ja ajas kinnistunud lähenemisest, mille najal on kasvanud kaasaegne kunstiteadus oma analüütiliste meetoditega, vaid vaja on ka teist - fenomenoloogilisele lähenemisele omast võimet leida side objekti väliste ja subjekti sisemiste kvaliteetide vahel, mis kokku liitununa annavad endast teada läbi kunstielamuse ja sellele omase subliimsuse erinevate avadlumisvormide, mida tõsi on sõnades raske väljendada ja mis lisaks põhjuste konkreetsele määratlemisele, nõuavad tähelepanu ka kõigele sellele, mida ehk ei olegi võimalik loogilise teksti maatriksite kaudu väljendada. Selleks, et kirjeldada kunstiteosesse kätketud geeniuse jälge, vajame nii hingelist pühendumust kui vaimu jõudu, mis otsib sidet meie eksistentsi kõige sügavamate allikatega. Üks võimalus visuaalse kujundi tõlkimiseks sõnalisse vormi on võtta kasutusele luulekunsti avarused ja sellele vastav keel, mis küll nii-

81 Jacques Derrida, The Truth in Painting (Chicago, London: University of Chicago Press,1987), 61. 82 Potts, Flesh and the Ideal. Winckelmann and the Origins of Art History, 69.

83 Pots dus ja üldlingvistika, 323. 
sama ebamäärasena ja lõpuni äraseletamatuna, võimaldab meil muuta kirjeldamatu kirjeldatavaks läbi kunstiteost kirjeldavate vormiliste ja pildina hinnatavate kujundite rea. Kunst on kunst, on kunst. Üritades seda lõpuni mõista, teeb meist igaüks seda oma vastutusel, on seejuures vaba kasutama ükskõik millist keelt (kunstimeediat ja teadust), mida taeva tahtel omame ja mis võimaldab meil saada aru ka sellest, mis on esimesel pilgul ja lihtsale mõistusele arusaamatu.

Juhan Maiste: Why does The Laocoön Speak In Words And Not In Marble?

Keywords: Laocoön; Winckelmann; Lessing; Herder; Goethe; Sublime; Phenomenology

SUMMARY:

In this article, the author focuses on the work called Laocoön, which was one of the most popular subjects for $18^{\text {th }}$ century art writers. The first description of the work was provided by Pliny the Elder who, in the $36^{\text {th }}$ volume of his Naturalis historia, calls it the best work of the art in the world - be it painting or sculpture. Pliny identifies three artists from Rhodes - Hagesandros, Polydoros and Athenedorus - as the authors of the Laocoön Group. After the sculpture was found in the vicinity of the Basilica of Santa Maria Maggiore, the Laocoön has repeatedly aroused the interest of art historians. Johann Joachim Winckelmann raised the sculptural group into focus during the Age of Enlightenment. And his positions, and sometimes opposition to them, form the basis of Gotthold Ephraim Lessing's, Johann Gottfried Herder's and Johann Wolfgang Goethe's writings on the Laocoön. ${ }^{84} \mathrm{I}$ am sure that their thoughts deserve

84 Lessing's, Herder's and Goethe's writings on Laocoön published in Laokoon. Lessing, Herder Goethe. Selections, ed. by William Guild Howard (1910) have been used in this article. During the past century, many of Howard's statements have been reassessed, but it is still the only treatment of the subject that views it as a whole, by collecting three of the root texts of the history of aesthetics in one volume: Gotthold Ephraim Lessing, Laokoon. Oder über die Grenzen der Malerei und Poesie. Mit beiläufigen Erläuterungen verschiedener Punkte der alten Kunstgeschichte (1766); Johann Gottfried Herder Abhandlung über den Ursprung der Sprache: Welche den von der Königl. Akademie der Wissenscahaften für das Jahr 1770 gesezten Preis erhalten hat (1772); Johann Wolfgang Goethe, Über Laokoon (1798). also attention today, when we speak about the fundamental change in philosophy, philology, and partially also in art history. In seeking an answer to Lessing's question, "Why does Laocoön not cry in marble but in poetry?" Can art speak? And if it can, how? The first stage of the article explores the contradictory nature of word and picture, in which regard both Lessing and Herder preferred the former. The second question that arises in the article is: What are the framework and boundaries of art writing as a method of art history for ascertaining and describing the internal nature of a work of art? And further, do words enable one to arrive at the deeper layers of a work and the reason for the act of creation? And if so, to what extent? The third and most important issue examined in the article is the two possible approaches to a work of art, and visual images more generally - the analytical and phenomenological. By relying on history, and the broadly accepted methods of the narrative, sociological, biographical, and other sciences contingent on it, the epistemological nature of art has remained outside the conceivable limits of scientific language. And as such, it has reduced the possibility of understanding pictures and finding them a place in today's scale of assessments; of speaking not only about the external and measurable parameters, but also about works of art as unique phenomena, in which an invisible and metaphysical content exists in addition to that which is inherent to the visible and the describable. Just as much as our rudiments of rationality and logical analysis help us to understand works of art, their impact relies on a subjective readiness to receive artistic experiences, which according to Goethe, transform the Laocoön into something affectively animated in the torchlight. Art is usually revealed by in-depth sources via the contemplative reflection that follows sensory experiences. Since Longinus's time, this has been described as sublimity, and it garnered supporters in the form of the Neo-Platonic authors of the Renaissance, whose role in $18^{\text {th }}$ century aesthetics is just as significant as the art history tradition based on classical archaeological research. In the writings of Winckelmann, and those who followed him, the two poles of this approach to art are tightly merged. The author's goal is to draw attention to ways of understanding and writing about art, besides the descriptive methods and those related to history; to those that focus on the processes related to the gnoseological side and to subconscious creation, and provide a place for words and their power to create ever newer and more expressive metaphors. One possibility for translating 
visual images into verbal form is to adopt the breadth of poetry and its language, which truthfully, being just as ambiguous and inexplicable as art, enables us to make the indescribable describable; via a work of art as the initial idea, and the work that informs us of this idea as a series of formed images that can be assessed as pictures that describe the spiritual image (or eidolon in Greek).

CV:

Juhan Maiste (b. 1952) is a professor and Head of the Department of Art History at the University of Tartu. As a prolific writer he has authored a large number of monographs and articles on architecture, classicism, cultural heritage, the philosophy and poetics of art history. His scholarly interests include Estonian and Livonian manor architecture, the phenomenon of park landscapes as well as the work of Johann Wilhelm Krause. In addition to teaching and research, Professor Maiste is the editor-in-chief of the Baltic Journal of Art History. 